University of Louisville

ThinkIR: The University of Louisville's Institutional Repository

Electronic Theses and Dissertations

$5-2009$

\title{
The quilt as concept.
}

Denise Mucci Furnish

University of Louisville

Follow this and additional works at: https://ir.library.louisville.edu/etd

\section{Recommended Citation}

Furnish, Denise Mucci, "The quilt as concept." (2009). Electronic Theses and Dissertations. Paper 472. https://doi.org/10.18297/etd/472

This Master's Thesis is brought to you for free and open access by ThinkIR: The University of Louisville's Institutional Repository. It has been accepted for inclusion in Electronic Theses and Dissertations by an authorized administrator of ThinkIR: The University of Louisville's Institutional Repository. This title appears here courtesy of the author, who has retained all other copyrights. For more information, please contact thinkir@louisville.edu. 
THE QUILT AS CONCEPT

\title{
By
}

Denise Mucci Furnish

B.A. University of Kentucky, 1972

B.F.A. University of Louisville, 2008

\author{
A Thesis \\ Submitted to the Faculty of the \\ Graduate School of the University of Louisville \\ in Partial Fulfillment of the Requirements \\ for the Degree of
}

\section{Master of Arts}

Department of Fine Arts University of Louisville

Louisville, Kentucky

May 2009 
Copyright 2009 by Denise Mucci Furnish

All rights reserved 


\title{
THE QUILT AS CONCEPT
}

\section{By}

Denise Mucci Furnish

B.A. University of Kentucky, 1972

B.F.A. University of Louisville, 2008

\section{A Thesis Approved on}

March 9, 2009

By the following Thesis Committee:

\author{
Thesis Director
}




\section{DEDICATION}

This thesis is dedicated to

\section{Guy M. Fumish}

whose dedication to education has made this possible. 


\section{ACKNOWLEDGEMENTS}

I would like to thank my major professor, Lida Gordon, for years of inspiration, guidance, and patience. I would also like to thank the other thesis committee members, Barbara Hanger and Dr. Mark Bernstein for their time and comments and Dr. Susan Jarosi for her assistance and inspiration. I would also like to thank Jan Graves for planting seeds and nurturing them along the way. 


\section{ABSTRACT \\ THE QUILT AS CONCEPT \\ Denise Mucci Furnish}

March 9, 2009

This thesis presents an overview of my current work in context with my entire body of painted quilts created over a span of twenty-eight years. From its foundation in Feminism, my work reflects the quilt as an art form and a metaphor for my life and the lives of women of my generation. I have used Semiotics as a tool for organizing and explaining the work. The study of signs and their referents make a chain of signification that helps explain the multilayered and conceptual nature of my work. The paper is divided into an introduction and seven chapters that represent seven concepts in a chain of signification that I use to define a quilt and its relationship to my life's work. 
TABLE OF CONTENTS

PAGE

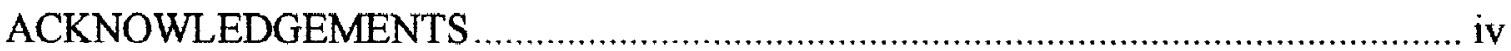

ABSTRACT

LIST OF ILLUSTRATIONS ................................................................................. vii

CHAPTER

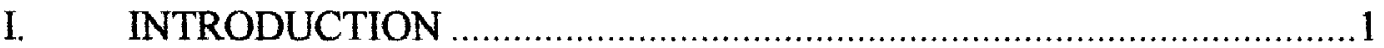

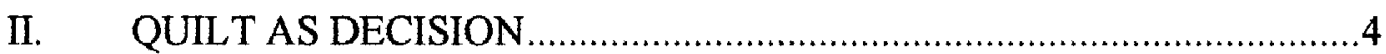

III. QUILT AS DECONSTRUCTION/RECONSTRUCTION ….....................

IV. QUILT AS LAYERS OF MEANING ….............................................10

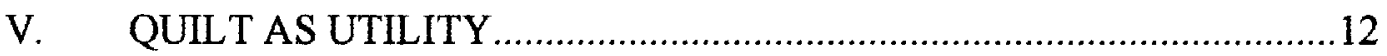

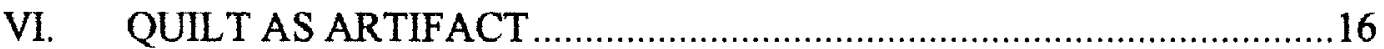

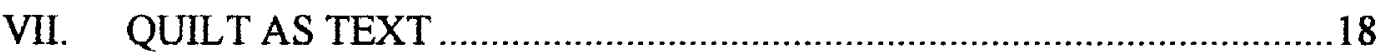

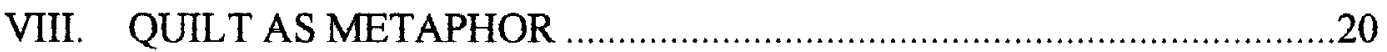

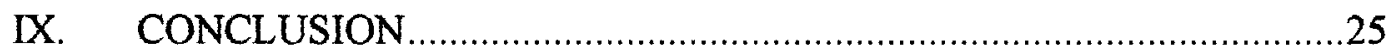

NOTES

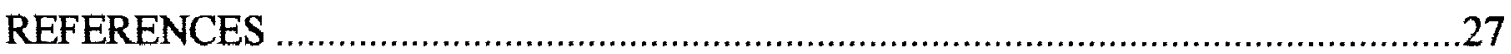

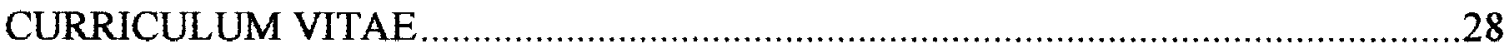




\section{LIST OF ILLUSTRATIONS}

\section{ILLUSTRATIONS}

PAGE

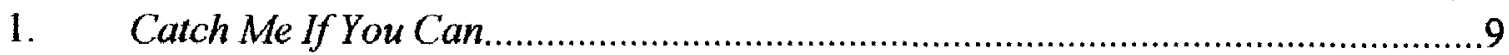

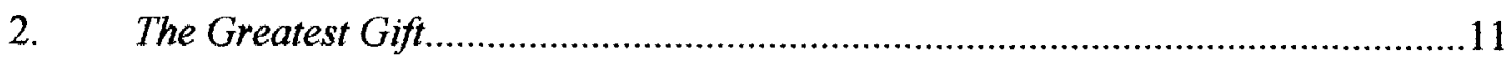

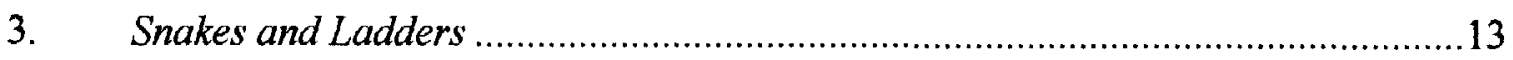

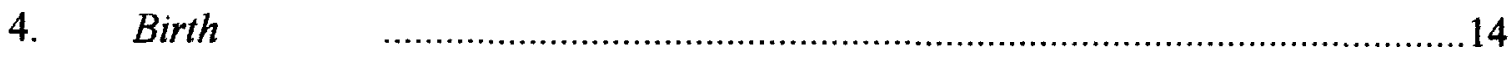

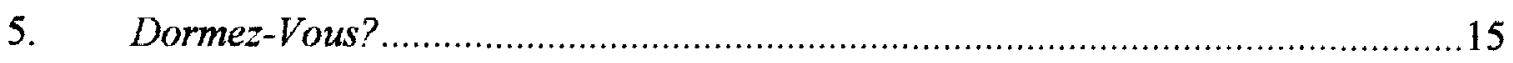

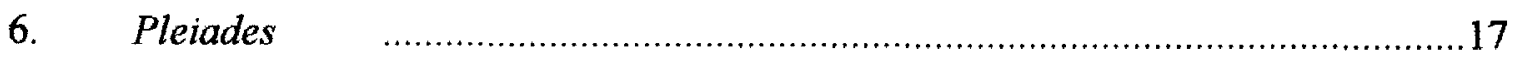

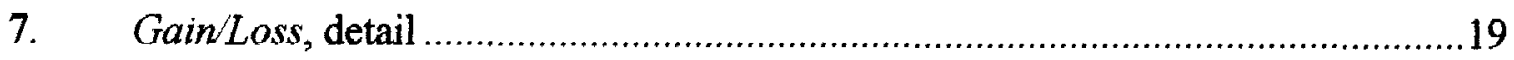

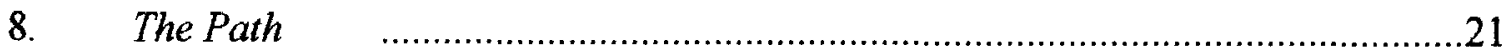

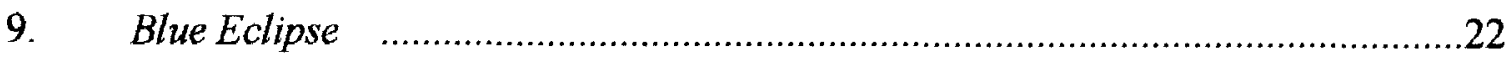

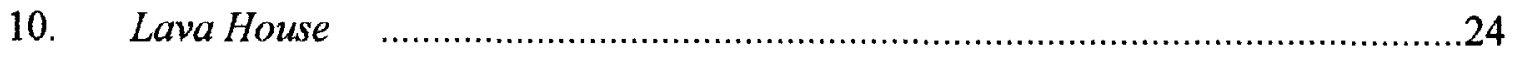




\section{INTRODUCTION}

I was asked, "What is a quilt?" It is a question that, at first, seems obvious, but the answer goes much deeper than a hand-made bedcovering. The process of defining a quilt is the essence of my art. The quilt is a sign of women's work. The making of a quilt implies a chain of signification through conception, use, deterioration, and, in my case, transformation.

I will use semiotics as a tool for organizing multiple layers of the conceptual and the material that make up my body of work. In this paper, I describe this work as a series of actions that interrelate in a chain of signification. The actions that describe the creation of a quilt are also the concepts that influence my transformation. I use the term quilt to describe both the found artifact and my painted resurrection, because they are at once the same and different. At other times, I refer to the finished work as painting because it is that, as well.

The quilt as a sign for bed interests me (see Quilt as Utility, below), yet I nearly always remove quilts from the bed and put them on the wall. For his collage, Bed, Robert Rauschenberg took a quilt from a bed and destroyed it to make art in 1955. The difference is that I am interested in taking already damaged quilts and transforming them into art. I later realized that seeing that work in the Museum of Modern Art in 1968 has influenced me. 
A quilt is a series of layers of fabric, layers of meaning, decisions of purpose and design. I am interested in the individual stories each quilt "knows"-as a witness to love and birth and dreams and death. I do not know these individual stories, only that they exist and have energy of their own. In transforming quilts, I interact with them in a way that is sometimes personal, sometimes metaphorical, and sometimes purely formal.

A quilt is shelter, adornment, and gift. A quilt is a story-a text that reveals a time in history, a vernacular. I am aware of its significance as both art history and women's history.

My work developed as a chain of signification beginning with the recognition of quilt as a sign of pre-feminist "women's work." This work was created and executed with attention to design and purpose. It was used, washed, worn. Often, it was separated from its maker. It was found by me and painted-a sign not only of transformation, but also of post-feminist women's achievement. The temporality of a chain of signification indicates its ever-changing nature, so the work constantly evolves according to my own conscious and unconscious fears and desires. "A signifying chain can never be complete, since it is always possible to add another signifier to it, ad infinitum." ${ }^{11}$ All of the signs in my work are interconnected, so my recent pieces refer to early works and vice versa.

Each action in the chain of signification describes the name of a chapter in this paper. The first action in the making of a quilt is a decision. It is a decision to conceptualize, and to design (Quilt as Decision). Then, there is a tearing or cutting of fabric into fragments and the reconstruction of fragments into a new whole (Quilt as Deconstruction/Reconstruction). There is layering (Quilt as Layers of Meaning). Then comes its use as gift, cover, decoration, protection, or witness (Quilt as Utility). If the 
quilt deteriorates and is discarded, it finds its way to me, as an artifact (Quilt as Artifact). At that point, my process of conceptualization and transformation begins. The transformation involves interaction with the artifact, sometimes by the use of text (Quilt as Text). The found quilt itself is a metaphor for women's experiences.

Furthermore, I create metaphors in the painting that is layered onto the quilt (Quilt as Metaphor). The last two chapters are most closely related to the current work in my thesis exhibit, the Yoyo Series, and the Surface Series, although these quilts contain traces of other concepts in the chain as well. 


\section{QUILT AS DECISION}

A quilter first has to decide what to make, why, and how to proceed. In effect, the quilt represents the process of creative decisions. Because of centuries of gender discrimination, needlework was one of the few avenues of creativity available to many women. So a woman's decision to make a quilt was often prescribed by the culture. If she were free to create what she wanted, to devote her life to art, her decisions might be very different. Yet under the circumstances, making a quilt fulfilled a personal as well as utilitarian need.

In The Second Sex, Simone de Beauvoir describes a dismal portrait of the bourgeois woman of leisure who often turned to creative work:

When she decides to paint or write merely to fill her empty days, painting and essays will be treated as fancywork: she will devote no more care and time to them, and they will have about the same value ... Accustomed to idleness, having never felt in her mode of life the austere necessity of discipline, she will not be capable of sustained and persistent effort, she will never succeed in gaining solid technique. She is repelled by the thankless, solitary gropings of work that never sees the light of day. ${ }^{2}$

By equating her unskilled writing and painting to "fancywork," Beauvoir describes the avenues open to creative women at the time.

Linda Nochlin challenges assumptions in the field of art history "in the very way of formulating the crucial questions of the discipline as a whole." ${ }^{3}$ Given the barriers in our education and institutional systems that held back women, Nochlin suggests that 
women never had the chance to make great art. The work of quilters-filled with beauty, harmony, rhythm, personal and societal symbols-never reached Nochlin's definition of great art:

The problem lies not so much with some feminists' concept of what femininity is, but rather with their misconceptionshared with the public at large-of what art is: with the naîve idea that art is the direct, personal expression of individual emotional experience, a translation of personal life into visual terms. Art is almost never that, great art never is. The making of art involves a self-consistent language of form, more or less dependent upon, or free from, given temporally defined conventions, schemata, or systems of notation, which have to be learned, or worked out, either through teaching, apprenticeship, or a long period of individual experimentation. The language of art is, more materially, embodied in paint and line on canvas or paper, in stone or clay or plastic or metal. It is neither a sob story nor a confidential whisper. ${ }^{4}$

By recognizing the work of marginalized cultures, and as a critique of white male dominance in the arts, contemporary artists have appropriated elements directly from quilting and needlework. They give a nod to the rich heritage that comes from women's crafts. Judith Brodsky and Ferris Olin, in making the case for the role of feminist art's influence on the advent of postmodernism, write,

Feminist artists used photography, video, film, assemblage, vitrines, murals, and performance to merge craft, popular culture, and high art. They also introduced fiber elements (decorative images from tiles and quilts, fabric, stitching, and embroidery) into painting. Through her use of repetitive decorative images in Hidden Chambers, Joyce Kozloff created paintings that celebrate women's craft and the traditional craft of other cultures. Kozloff, along with such artists as Robert Kushner, Ned Smythe, and Kim McConnel, is a member of the pattern and decoration movement inspired by Miriam Schapiro, who created "femmage," a new style of painting that incorporates fabrics and cloth trims into the surface of the painting. The influence of the pattern and decoration artists can be seen in 
the work of contemporary younger artists like Ghada Amer. ${ }^{5}$

As a young art student in the nineteen sixties, I found no female role models in my art history books, and little support from my male professors. Feminism was particularly energizing for me as an artist when I discovered Judy Chicago, Miriam Shapiro, and newly "uncovered" female artists from the past. It was after reading Chicago's book, Through the Flower, My Struggle as a Woman Artist, about her experiences in art school that I decided to use worn and discarded quilts as my canvases. The interwoven chains of signification and the beauty of worn quilts have held my interest for twenty-eight years. 


\section{QUILT AS DECONSTRUCTION/RECONSTRUCTION}

There is a tearing-fabric scraps, flour sacks, and for those with means, whole pieces of fabric were ripped or cut into shapes to be sewn together. Judith Elsley compared the act of tearing to rape in Alice Walker's book, The Color Purple:

In fact, a quilt cannot come into being without that tearing. This deconstructive act is, paradoxically... also one of the quilter's most creative acts...Tearing seems like a singularly appropriate place for woman to begin, whether with a quilt or with finding a way to autonomy, because being torn is so familiar an experience for women.

For more on this, see Quilt as Text, below.

The cut or torn pieces of cloth are assembled into a whole, focusing on aestheticsdesign, color, and placement-with special attention paid to the quilt pattern itself. These patterns are significant in the lives of the quilt makers. Quilt titles reflect local color, available resources, and their cultural and historical context. Pattern names indicate location ("Kentucky Star"), use ("Double Wedding Ring"), events ("Wild Goose Chase"), places ("Courthouse Steps," "Log Cabin"), shapes ("Eight Pointed Star"), and ideas ("Chinese Ten-thousand Perfections"), to name just a few. I am interested in the particular vernacular of quilt names as stories, and the patterns of the fabrics as indices of popular design, from late nineteenth-and early twentieth-century calicoes to art deco designs on flour sacks in the 1930 's, to "atomic" prints in the 1950's, and "mod" designs in the 1960's. The vernacular reflects local color, locally available resources and an evolution over time of environmental, cultural, and historical context. 
My painting titled Catch Me If You Can (1980) utilizes a rescued "Circle and Square" quilt that I over-dyed and painted with the "Catch Me if You Can" pattern in metallic gold. The fact that it is worn is obvious. It is old, yet it is new. The traditional pattern, "Catch Me If You Can," represents, to me, a dare from women to the patriarchal world- "Just try to stop us now." It was particularly interesting to me as a symbol for the emerging Women's Movement. The four spinning chevrons of the design echo an ancient pre-patriarchal symbol, similar to the swastika. It represents the four directions, or the four winds. The pattern goes by other colorful names: "Flyfoot," "Chinese Ten-Thousand Perfections," and "Wind Power of the Osages." 


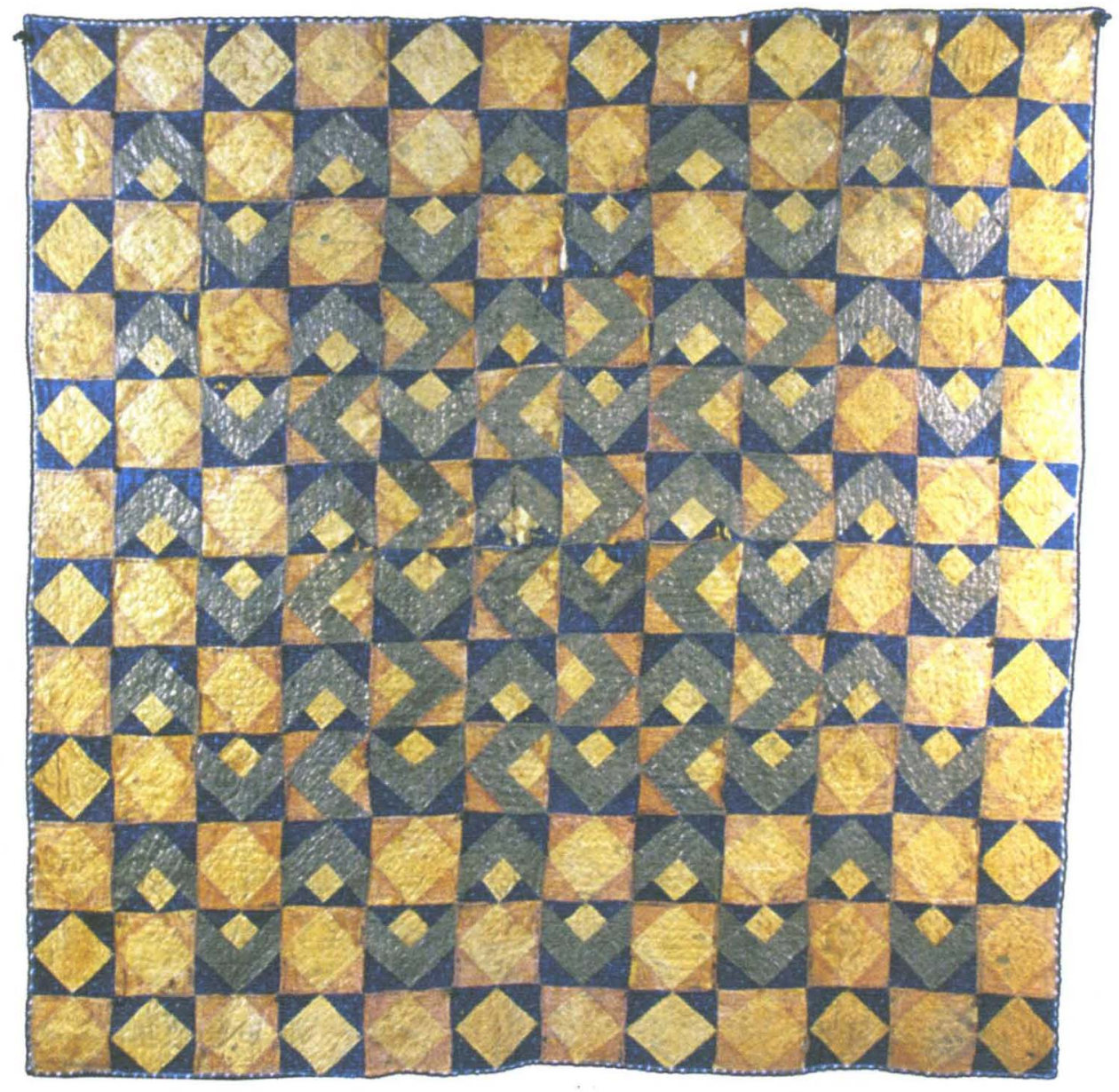

Catch Me If You Can (1980) 


\section{QUILT AS LAYERS OF MEANING}

Physically, a quilt is made of three layers: a (usually) pieced or appliquéd top, an inner layer of batting, and a back. The layers are sewn or tied together. There can also be layers of printed fabric, the pattern of the design, and the conscious and unconscious layers of meaning that come from the maker.

On top of the tattered quilt, I add physical layers of acrylic paint and acrylic medium mixed with pigment. Onto this surface, elements are added based on my intellectual interactions with the quilt itself such as mythology, nature, or other quilt patterns and methods of construction. Into this chain of signification are added layers of unconscious psychological fears and desires, such as volcanic eruptions or honeybees. I often do not realize until later what the meaning was, as in this painting, on a "Grandmother's Flower Garden" quilt. As a memorial to my grandmother, The Greatest Gift is about the binary nature of love. 


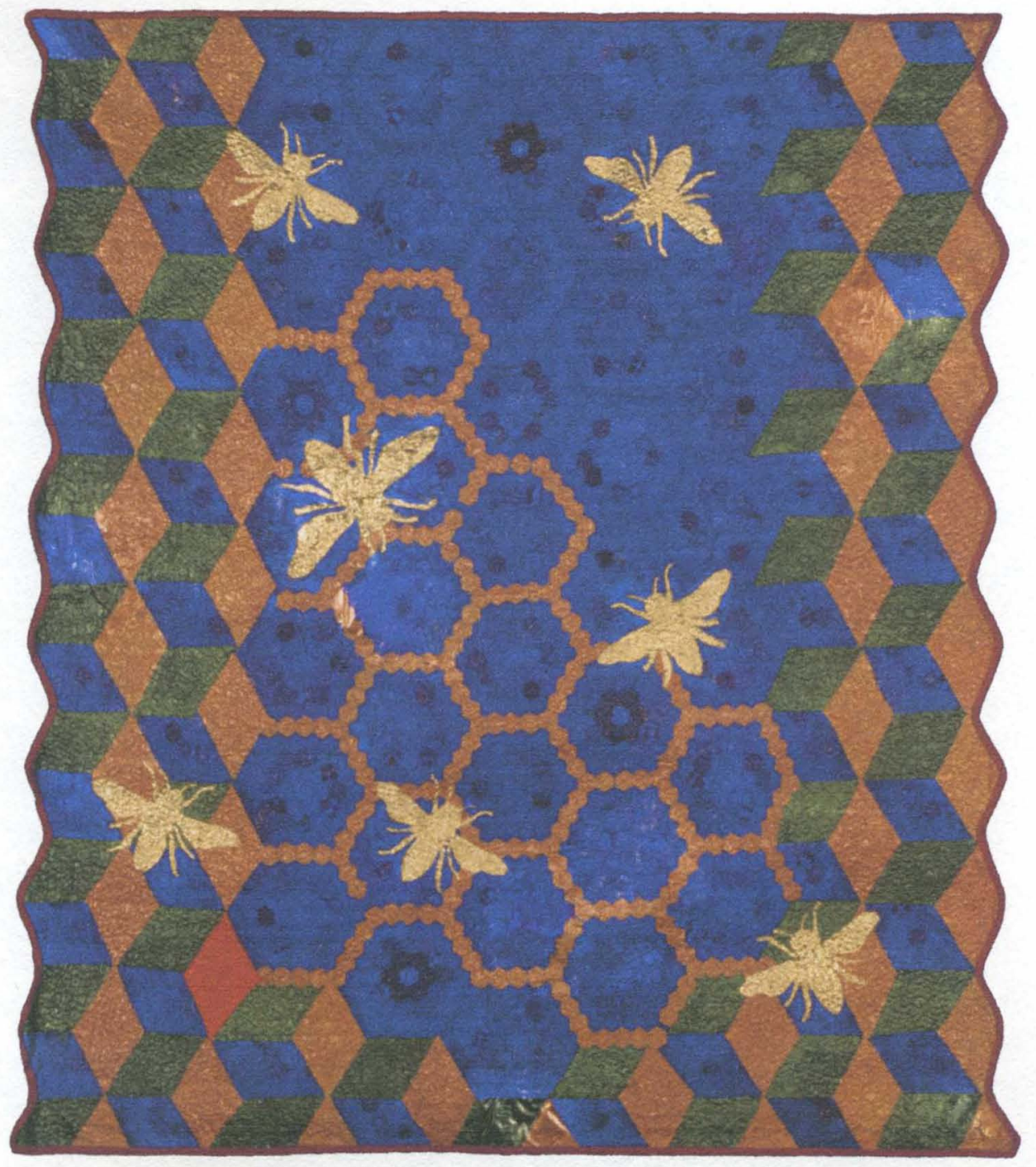

The Greatest Gift (1992) 


\section{QUILT AS UTILITY}

The primary purpose of a quilt is utilitarian: it is made to cover a bed. Fragments were first pieced together as a thrifty way of using up scraps from clothing. In the Folk Art Museum in New York City, the accompanying signage to a 2008 exhibit, titled Recycling and Resourcefulness, Quilts of the 1930 's, captures the feeling of post depression America:

Use it up

Wear it out

Make it do or do without

Many of the fabrics in these depression-era quilts were made from flour sacks. Knowing their appeal, savvy mills printed sacks with colorful art deco and calico patterns.

Quilts were often used as gifts for oneself or another. In Snakes And Ladders (1985), I rescued a "Double Wedding Ring" quilt and highlighted images of snakes that were hidden within the locking rings. Historically, "Double Wedding Ring" was often given as a trousseau gift for a bride. Snakes and Ladders was a popular children's game in which players moved about on a board, climbing ladders, trying to reach the top, but often encountering snakes along the way. A more recent (and lighter) incarnation of the game is called Chutes and Ladders. The painted addition of game imagery on top of a trousseau quilt suggests the aspirations and dangers/pleasures of marriage, including the 
Freudian interpretation of snakes as phalluses and the Jungian interpretation of ladders as a collective reaching for Divine wholeness.

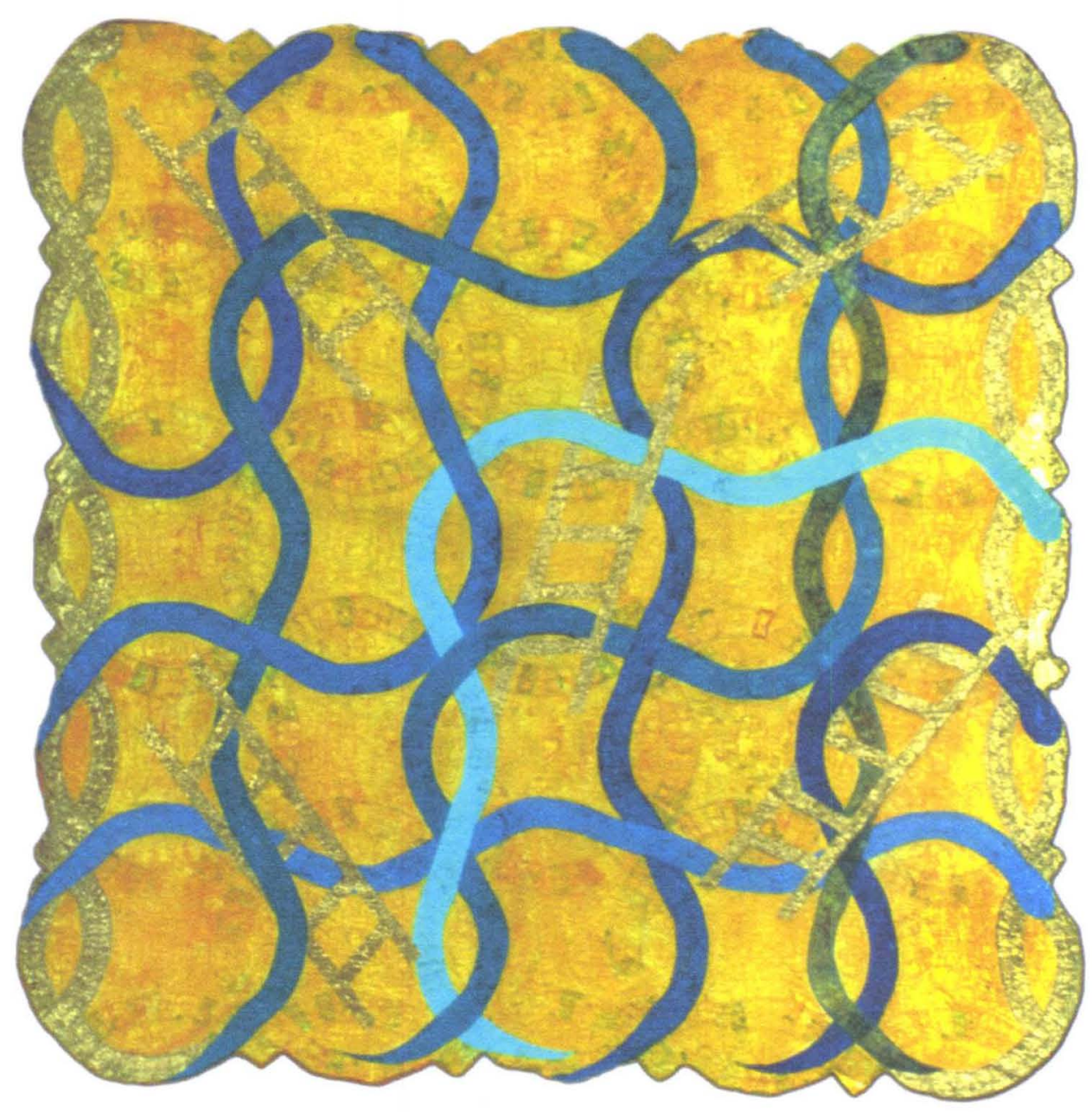

Snakes And Ladders (1985)

Another sign of utility is witness. By covering a bed, quilts are witnesses to the cycles of love, birth, death, and sleep. My Life Cycles series of 1996-1997 examines some of life's major events. Birth (1997), a "Double Irish Chain" quilt fragment, 
dedicated to my Irish mother, is one of this series. Others are Stepping Out, Commitment, and Leaving.

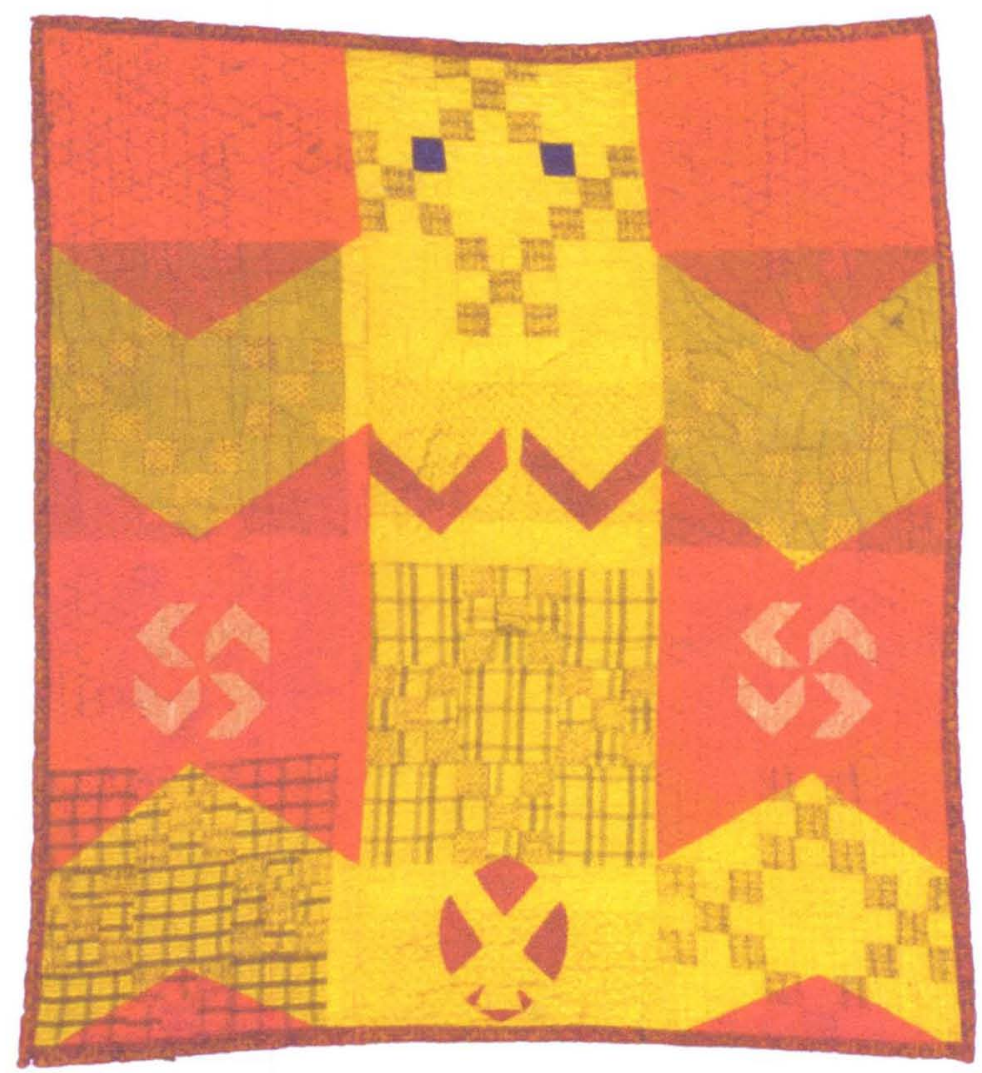

Birth (1997)

As a bed cover, a quilt is also a witness to sleep. Dormez-Vous? (2006) asks, "Are you sleeping?" The rescued quilt is a "Texas Lone Star," and it was made during the presidential administration of George W. Bush, who is from Texas. I felt that the country was slipping into a dangerous somatic state. The piece is formalist and textured. There is a shadowy darkness lurking behind the purple highlights. It is the first of my minimal Surface Series. 


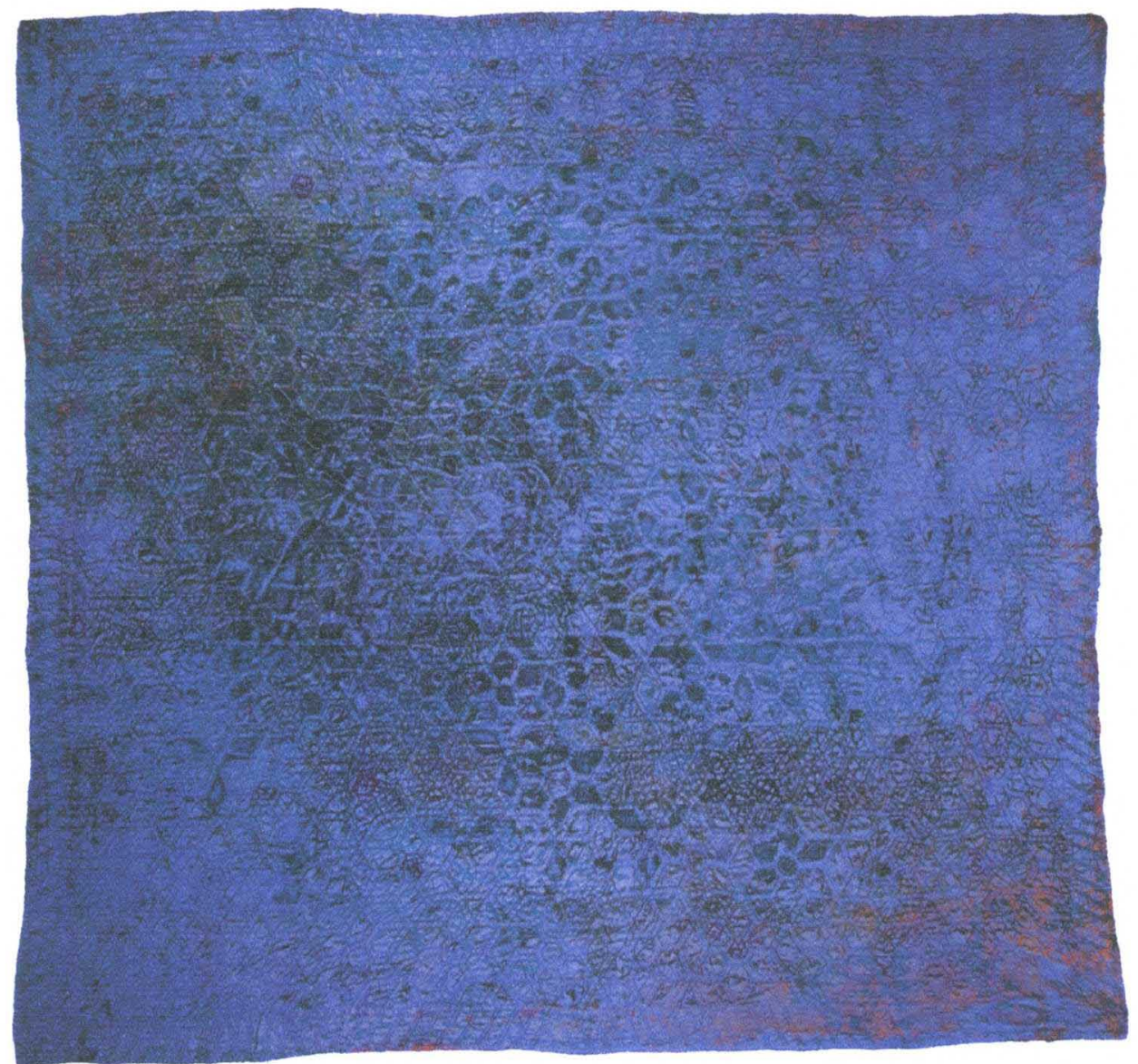

Dormez-Vous? (2006) 


\section{QUILT AS ARTIFACT}

One definition of the word "artifact" is "an object shaped or produced by human craft." Another definition is "Something viewed as a product of human conception or agency rather than an inherent element: 'The very act of looking at a naked model was an artifact of male supremacy' (Philip Weiss)." In transforming quilts as artifacts, both of these definitions are used. The quilt is treated as both an object produced by human craft and as a result of its having been created, used and discarded. Some of my work calls particular attention to the ways in which it was created, used, or found.

In a junk store on US 60 between Louisville and Frankfort, Kentucky I found a gaudy 1960's comforter: floral sheets had been sewn over some batting and tied together with yarn. But when I inspected it closely, the batting used was, in fact, a worn out "Rolling Star" quilt. This handcrafted artifact was created from the quilt's deterioration and the thrift of the person who reconstructed it as a comforter. In the same way my work is a result of a quilt's deterioration. In Pleiades, my painting that incorporates this quilt, the sheet is pulled back, exposing part of the quilt inside, then over-dyed and painted. The title of the work references the constellation Pleiades, or Seven Sisters, which is painted into the old quilt. The Seven Sisters are Greek daughters of the night, whose genealogy is often contradictory, but whose name refers to "sisterhood," a feminist term used to indicate solidarity. The stars in the quilt are configured in nearly the same way as those in the night sky. Pleiades is faint and can barely be seen on clear dark nights. The piece 
suggests what is hidden and what is revealed. The constellation emerges from beyond the surface of the earth, which is made from the remaining yarn-tied sheet. By leaving the sheet on the lower part of the quilt, I emphasize the nature of the object that went through multiple stages of creation, use, deterioration and re-use. The sheet-clad earth is painted with leaves, so it is hidden as well.

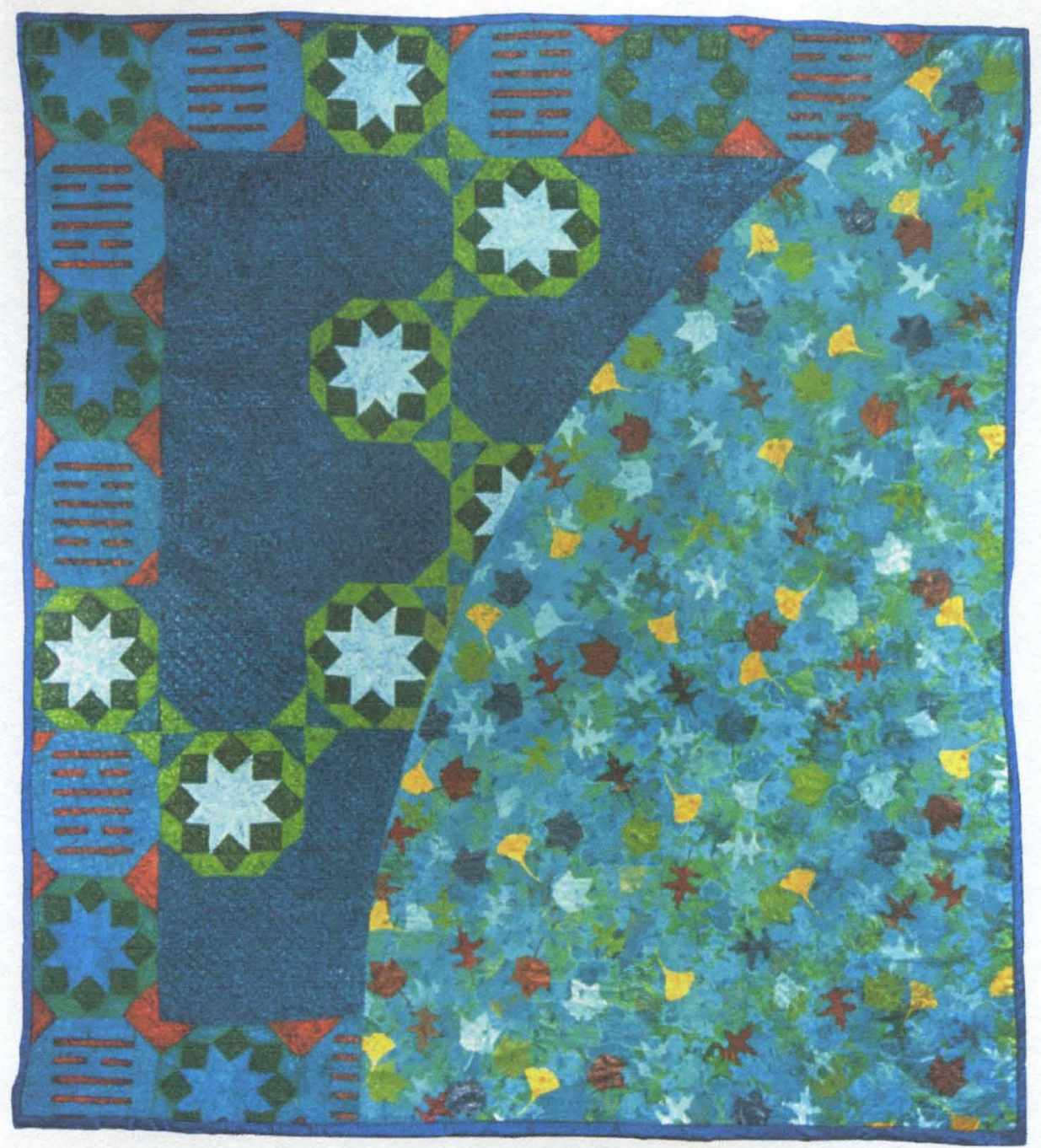

Pleiades (1995) 


\section{QUILT AS TEXT}

Elsley wrote, "A quilt is a text. It speaks its maker's desires and beliefs, hopes and fears, sometimes in a language a reader can understand, but often in an obscure language available only to the initiated." such as Alice Walker's The Color Purple. And, as was mentioned earlier, she compared the tearing of fabric to the rape of women-Celie in particular, and then traced her healing to the reconstruction of a quilt. "Sewing is one way for women to begin the process of self-reclamation because it represents, more than other activities traditionally associated with women, a powerful and elemental connection."

In addition to the quilt itself as text, I sometimes add writing to quilts. In an excerpt from her poem, Looking at Quilts, Marge Piercy wrote:

Out of death from childbirth at sixteen, hard work at forty, out of love for the trumpet vine and the melon, they issue to us:

$$
\begin{aligned}
& \text { Rocky Road to Kansas } \\
& \text { Job's Troubles } \\
& \text { Crazy Ann, } \\
& \text { The Double Irish Chain }
\end{aligned}
$$

The Tree of Life:

$$
\text { this quilt might be }
$$

the only perfect artifact a woman would ever see, yet she did not doubt what we had forgotten, that out of her potatoes and colic, sawdust and blood she could create; together, alone, she seized her time and made new. ${ }^{10}$ 
I wrote this excerpt in paint onto my quilt titled Changes. The poem evokes my experience as a young artist with three small children. The name Changes refers to the personal and artistic growth I experienced as a result of my discovery of the quilt as a concept that I could use to propel my work.

The Yoyo Series (2005) consists of collages on canvas using "Yoyo" quilt circles, archival digital ink on cotton, and acrylic. The added text indicates, as a yoyo, fluctuations between extremes, as in the stock market crash of 1929, or yoyo dieting (Gain/Loss). Others in the series include Yes/No and Love/Fear. The "Yoyo" quilt was first made in the 1930 's, after the Great Depression. It was created as a thrifty way of using small scraps of fabric. It is made not by sandwiching layers fabric, as in a traditional quilt, but by cutting out circles, basting them around the edges with needle and thread, and gathering the fabric into ruffled discs that are stitched together at four opposite points. The quilt is visually light, yet it reflects serious options.

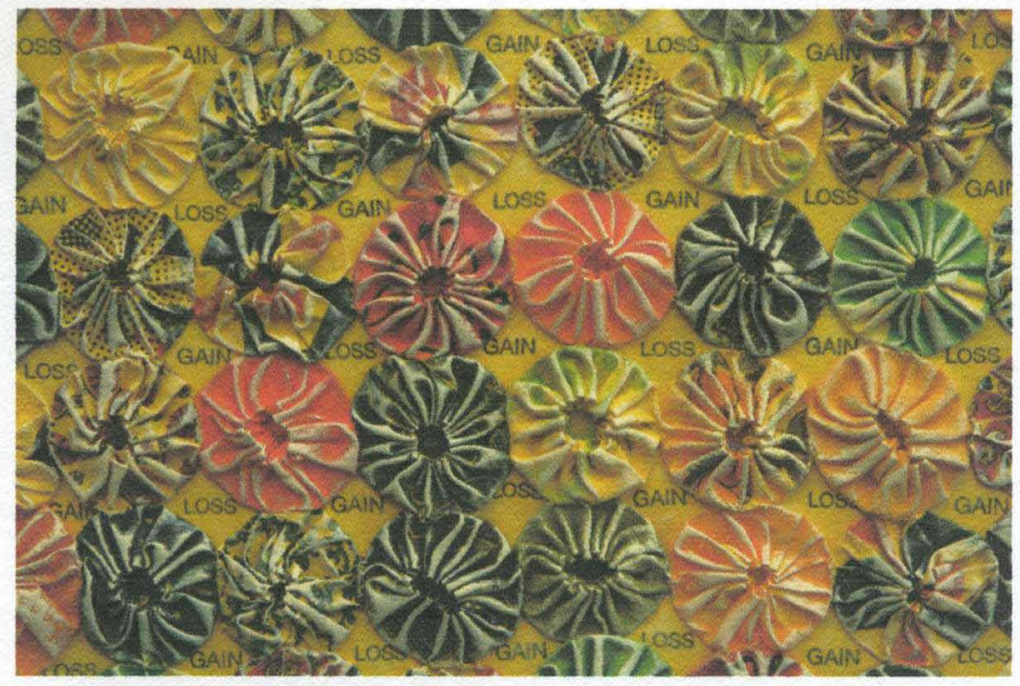

Gain/Loss, detail (2006) 


\section{QUILT AS METAPHOR}

Quilting is a source for metaphors in contemporary literature. Quilting bees, pattern names, and techniques can be used to describe women's experiences, as in Alice Walker's The Color Purple, mentioned above. Originally, the quilt was, for me, a metaphor for women's creativity that had been stifled by patriarchal oppression. The quilt patterns are a metaphor for the richness of women's lives in spite of their circumstances.

In the past, I retained the fabric designs that made up the quilt patterns by using transparent color. The Path is the first quilt in which the fabric design is deliberately hidden, although the quilt pattern is still slightly visible and is utilized as a grid for the painted paths. In this quilt, an "Eight Pointed Star" quilt, I traced two intersecting paths, a golden path and a shadow path, that are metaphors for the choices we make in life. A thin veil of white further obscures the whole piece. 


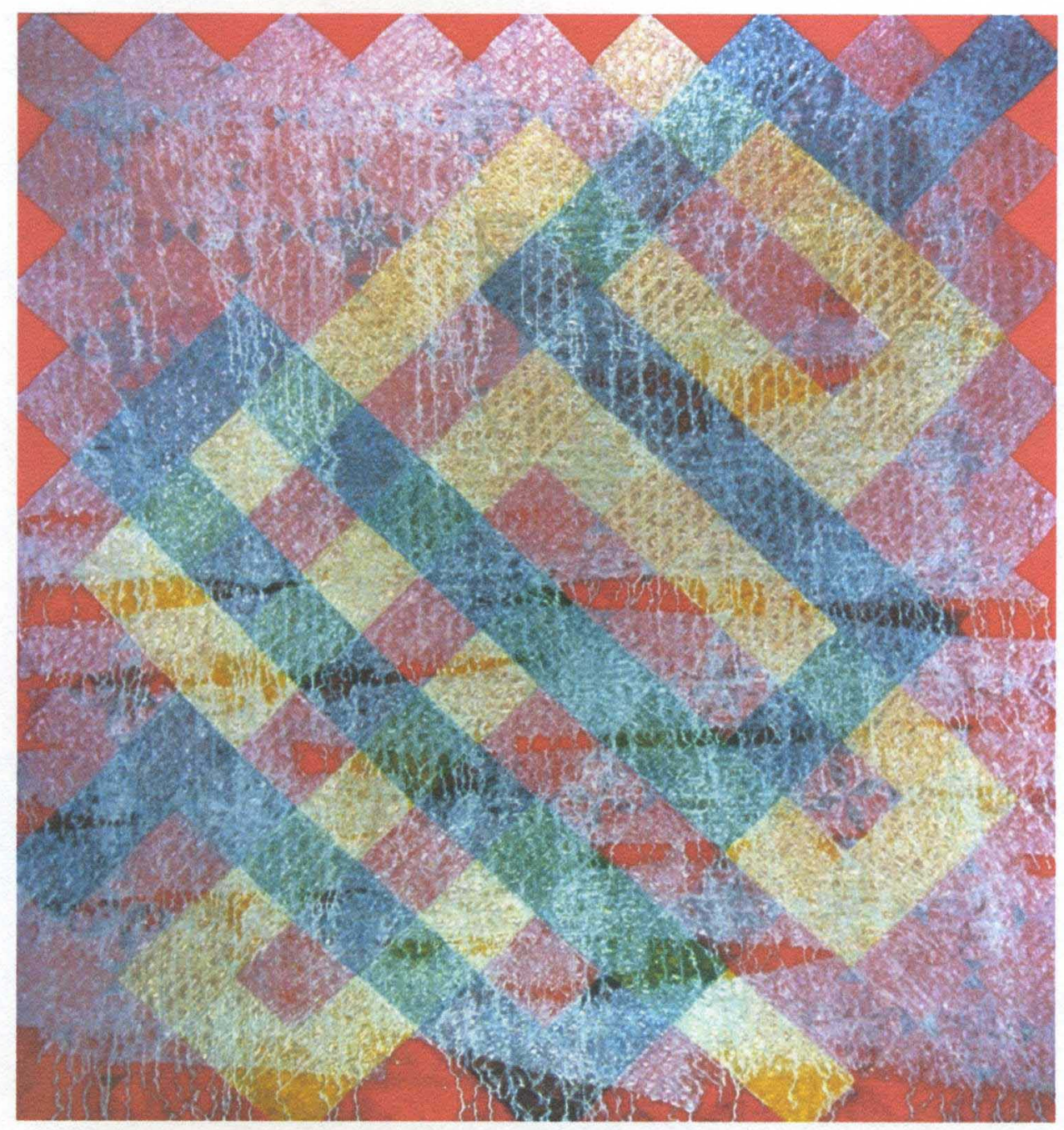

The Path (2001) 
Blue Eclipse is a "Yoyo" quilt laminated onto canvas and painted. The fabric designs are covered, yet the yoyo structure is important. The circle of the eclipse echoes the circular yoyos. This piece is formal, and is a metaphor for things partially hidden and revealed.

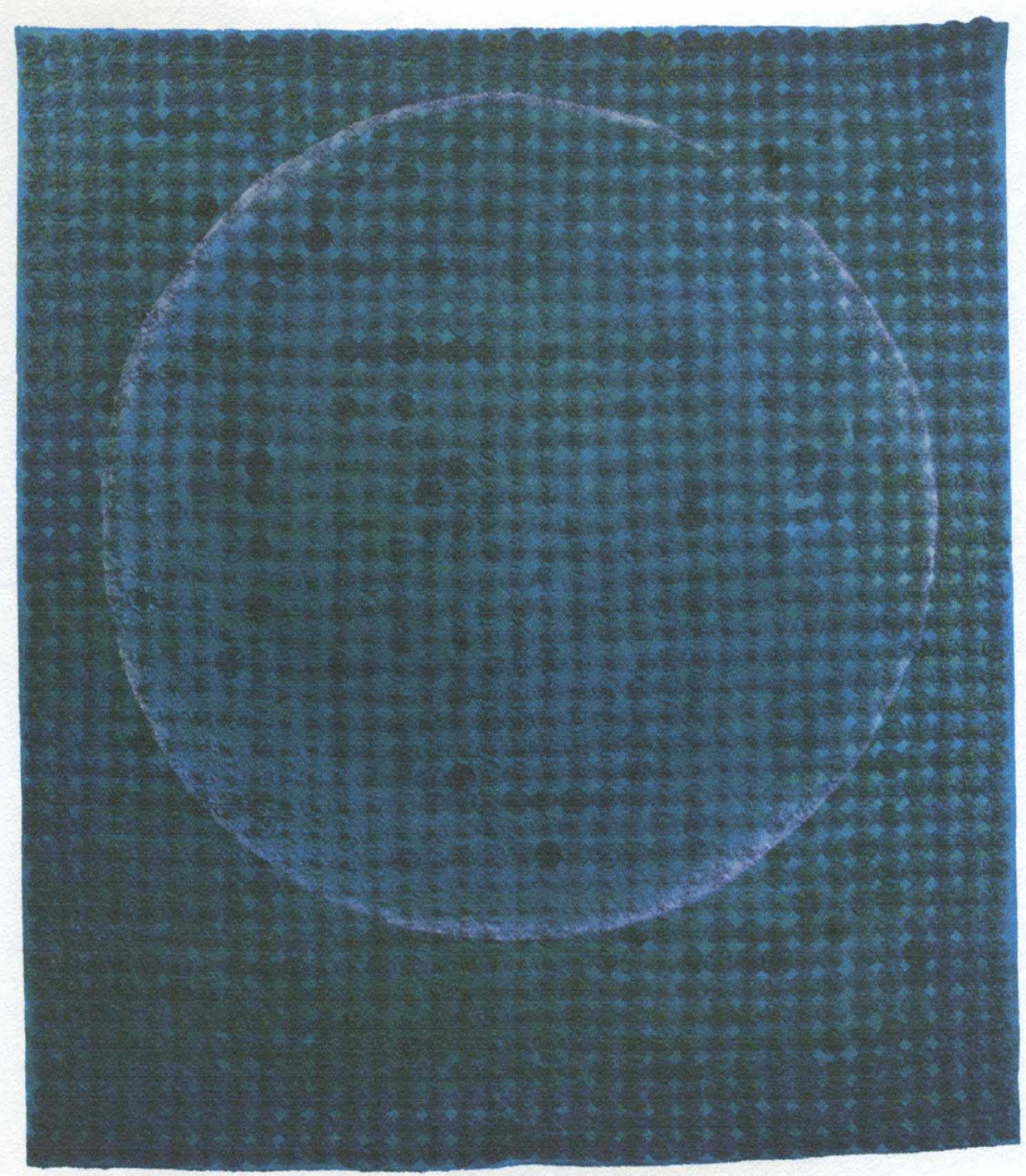

Blue Eclipse (2006) 
The Surface Series lets go of fabric design and quilt pattern and concentrates on the worn surface and structure of the quilt stitches that hold it together. The worn quilt becomes a metaphor for aging. The pattern becomes invisible, as an aging woman becomes invisible. It is not without difficulty that I obscure the pattern and fabric design that give a quilt its identity. The scars and deteriorating fabric are significant, and combine with the quilting stitches to provide a rich surface. Often, an entire area has dissolved due to the type of dye used, leaving only cotton batting and thread. This creates texture that is enhanced by the addition of layers of color, sometimes as many as twenty. Hidden beneath the worn surface layers of paint dwells a history, a trace of what went before.

One of the Surface Series, called Lava House is painted on a "Tea Party" quilt. The name comes from a local arts community that suffered a tragic loss to fire. Volcano imagery has regularly appeared in my work, both on personal and universal levels, as a metaphor for the built-up and explosive creativity that accompanied the Feminist Art Movement. 


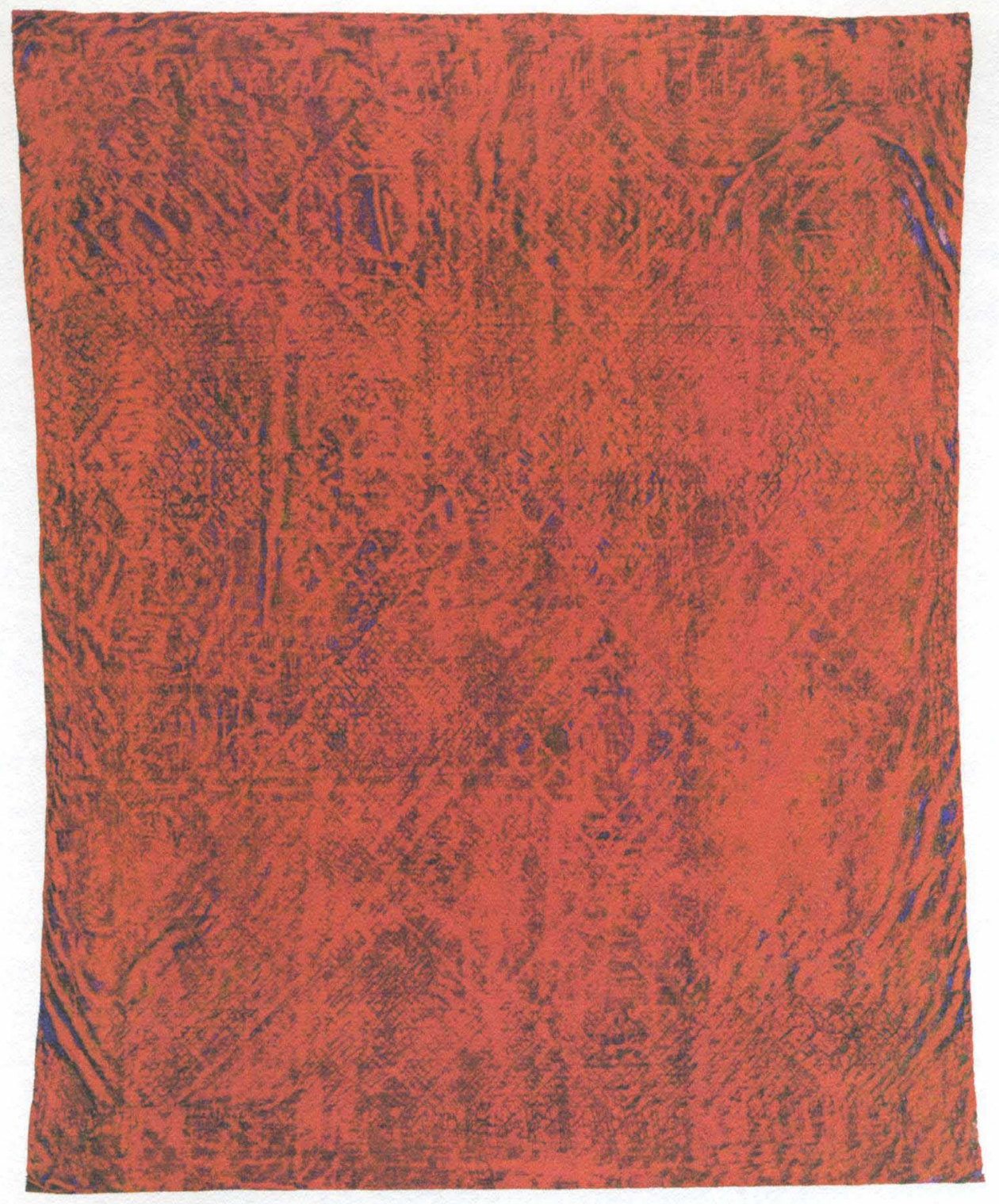

Lava House (2008) 


\section{CONCLUSION}

My decision to use discarded quilts, a craft medium most commonly associated with women's domestic work, recognizes that these artifacts have value as material repositories/artifacts embedded with the decisions of their makers-aesthetic, utilitarian, and creative. As a painter, I appropriate the remains of quilts and paint on them, interacting with their form, pattern, and surface.

I have used the concept of the quilt, from the early days of the women's

movement in Louisville, to this, my $60^{\text {th }}$ year. I have seen my work evolve from 1980 as a commentary on the quilt itself as a sign of women's visibility in the arts, to the present as a sign of the invisibility and deterioration as well as strength and beauty of older women. 


\section{NOTES}

1. Evans, Dylan. An Introductory Dictionary of Lacanian Psychoanalysis. (New York: Brunner-Routledge, 1996), 188.

2. Simone De Beauvoir, The Second Sex (New York: Knopf, 1952), 739.

3. Linda Nochlin, Why Have There Been No Great Women Artists? In Women, Art, and Power (New York: Harper \& Row, 1988), 146.

4. Ibid., 149

5. Judith K. Brodsky and Ferris Olin, Stepping out of the Beaten Path: Reassessing the Feminist Art Movement. Vol. 33, no.2 of Signs: Journal of Women in Culture and Society (2008): 337,338.

6. Judith Elsley, Quilts as Text(iles); The Semiotics of Quilting Vol. 16 of Berkeley Insights in Linguistics and Semiotics. (New York: Peter Lang Publishing, 1996). 4.

7. The American Heritage Dictionary, 3d Ed., s.v. "artifact," (Philip Weiss)

8. Elsley, 1.

9. Ibid., 9 .

10. Marge Piercy, "Looking at Quilts" in Circles in the Water (New York: Alfred A. Knopf, 1982), 171. 


\section{REFERENCES}

Chicago, Judy. Through the Flower, My Struggle as a Woman Artist, New York:

Doubleday, 1975. 


\section{CURRICULUM VITAE}

Denise Mucci Furnish

2568 Woodbourne Avenue

Louisville KY 40205

Born in Louisville, Kentucky, October 18, 1948

\section{Selected Exhibitions}

\section{NATIONAL, INTERNATIONAL}

The Artist as Quiltmaker XIII, Firelands Association for the Arts, Juried, Oberlin, OH 2008

Puzzled and Bored, The New England Quilt Museum, Invitational, Lowell, MA 2008

Art Quilts at the Sedgwick, Juried, Philadelphia, PA 2006

The Artist as Quiltmaker XII, Firelands Association for the Arts, Juried, Oberlin, $\mathrm{OH}$ 2006

Encompass, Argdillan Castle, Dublin, Ireland, Invitational, 2004

Here \& There: Exploring Regionalism, Michael Wardle Gallery, Invitational, Las Vegas, NV, 2003

Art in the Embassies Program, American Embassy, Invitational, Lisbon, Portugal, 1998-2001

Contemporary American Quilts, Crafts Council, Invitational, London, England, 1993

Contemporary American Quilts, Crafts Council, Invitational, Dublin, Ireland, 1993

Inception, Gallery 108, Invitational, New York, NY, 1993

Contemporary Quilts USA, US Information Agency International Tour, Invitational, 13country European tour, 1991-1993

Long Island Quilter's Society Invitational, Mineola, NY, 1989

Re-defining the American Quilt, Pennsylvania State Art Gallery, Invitational, 1987

Contemporary Quilts, Boston University Art Gallery, Juried, Boston, MA, 1986 


\section{REGIONAL}

The Yoyo Sisterhood: Four Perspectives, One Pattern, Garner-Furnish Studio Louisville KY 2006

LAFTA Show, Juried, Kentucky Museum of Art and Craft, 2004

The Tree of Life Project, Louisville Area Fiber and Textile Artists, The Water Tower, Louisville, KY, 2002, Bernheim Arboretum; Clermont, KY, 2001

Kentucky Quilts: Roots And Wings, Traveling show, Invitational, The Folk Art Museum, Morehead, KY, 1999

Re-Volution: Quilts and Altar Cloths, Kentucky Art and Craft Foundation, Two person show, Louisville, KY, 1997

Denise Mucci Furnish: Quilts and Prayer Cloths, Inspirations Gallery, One person show, Louisville, KY, 1996

The Art of the Book, The Kentucky Art and Craft Gallery, Invitational, Louisville, KY, 1995

Quilt Conceptions: Designs in Other Media, Kentucky Art and Craft Gallery, Invitational, Louisville, KY, 1992

Transformations: Feminist Art by Louisville Artists, Louisville Visual Art Association, Invitational, 1990

Artist 's and their Children, Liberty Gallery, Invitational, Louisville, KY, 1988

Color, Shape, Texture: Painterly Approaches to Quiltmaking, The Water Tower, Invitational, Louisville, KY, 1986

Denise Mucci Furnish: Quilts, Loho Gallery, Two-person show, Louisville, KY, 1986

Eight States Annual: Crafts, JB Speed Art Museum, Juried, Louisville, KY, 1985

Kentucky Revisited, an Overview of Kentucky Artists, State Capitol, Invitational, Frankfort, KY, 1984

Mid-States Crafts Exhibition, Evansville Museum of Fine Arts, Juried, Evansville, $\mathbb{N}$, 1982

Eight States Annual: Graphics, JB Speed Art Museum, Juried, Louisville, KY, 1981

The Earth Show, Louisville Visual Art Association, Juried, Louisville, KY 1981

Louisville Quilts, An exhibition of quilts created in celebration of the LouisvilleJefferson County Bicentennial, Louisville Art Gallery, 1980 


\section{Awards and Grants}

Juror's Choice Award of Excellence, the Artist as Quiltmaker XIII, Oberlin, Ohio 2008 KY Arts Council, Artist In Residence Grant, 2003

Frankfurterhof Arts Center, Mainz, Germany, 2001 Louisville Sister Cities, Mainz Committee

Ky. Foundation for Women's Fellowship in the Visual Arts, Two week fellowship, Mary Anderson Center for the Arts, 1995

Kentucky Women Artist's Fellowship Program, Six week fellowship, Virginia Center for the Creative Arts, 1994

Artist's Grant, Kentucky Foundation for Women, 1989

\section{Selected Collections}

Ohia Design, Honolulu, Hawaii

Rocky's, Louisville, Kentucky

Senior Care, Louisville, Kentucky

Morton Salt, Weeks Island, Louisiana

Peoples Bank, Shepherdsville, Kentucky

NTS Corporation, Louisville, Kentucky

Brown Forman Corporation, Louisville, Kentucky

Peter's Construction Company, Louisville, Kentucky

Eldercare Solutions, Louisville, Kentucky

Sallie Bingham, Santa Fe, New Mexico

Creative Balance, Louisville, Kentucky

Home of the Innocents, Louisville, Kentucky

The Mattingly Center, Louisville, Kentucky

Robinette and Associates, Georgetown Indiana

Kentucky State Parks

\section{Education}

MA, University of Louisville, 2009

BFA, University of Louisville, 2008

Attended Louisville School of Art, 1980-1981

BA, University of Kentucky, 1972 